\title{
BRUNO'S ORGANIC UNIVERSE AND THE NATURAL MAGIC
}

\author{
Ph.D. Candidate Zheng WANG \\ Civiltà del Rinascimento, Scuola Normale Superiore \\ ITALY, \\ Email: zheng.wang@sns.it
}

\begin{abstract}
Giordano Bruno (1548 - 1600) is regarded as the principal representative of the infinite and homogenous universe. Bruno has a modern rational mind by no means. However, his doctrine has so deeply influenced the reconstruction of a modern understanding of the material of universe and human body. His process of rebuilding the cosmology and humanity consists in learning the individual's psychical condition and the relations between society and man. The links between the components of the brunian organic universe can be generated spontaneously from "love-Eros" for the mundane life of its infinite expansion. And in his organic universe, Bruno considers and desires all beings to be alive, all to be animated. And from this doctrine, his predilection for the magic is derived, which is based precisely on the presupposition of a universal "panpsychism" aiming to take possession of the natural world with artifices.
\end{abstract}

Keywords: Organic universe; Natural magic; Infinity; Material; Link; Love-Eros

\section{INTRODUCTION}

"As for Giordano Bruno, it is with a burning enthusiasm-that of a prisoner who sees the walls of his jail crumble-that he announces the bursting of the spheres that separated us from the wide-open spaces and inexhaustible treasures of the everchanging, eternal and infinite universe",

With these words above, Alexandre Koyré includes Bruno among the protagonists of this:

\begin{abstract}
"scientific and philosophical revolution", who bring forth "the destruction of the Cosmos, that is, the disappearance, from philosophically and scientifically valid concepts [...] of the world as a finite, closed, and hierarchically ordered whole" to a substitution of "an indefinite and even infinite universe which is bound together by the identify of its fundamental components and laws, and in which all these components are placed on the same level of being",
\end{abstract}

It is Giordano Bruno who has to be regarded as the principal representative of the doctrine of the decentralized, infinite and infinitely populous universe. The essential infinitude of the space has never been ascertained in such an outright, definite and conscious manner before Bruno. Already in his Italian dialogues La Cena de le Ceneri (1584),

\footnotetext{
${ }^{1}$ Koyré, Alexandre, From the Closed World to the Infinite Universe, Johns Hopkins University Press, Baltimore, 1957, p. 43.

${ }^{2}$ Ibidem, p. 2.
} 
Bruno has acknowledged the drastic refutation of the classical Aristotelian and Ptolemaic doctrine which is against the idea of the motion of the earth. He proclaims that "the world is infinite and that, therefore, there is no body in it to which it would pertain simpliciter to be in the centre, or on the center, or on the periphery, or between these two extremes"3 of the world, but only to be among other bodies. As for the world which has its cause and its origin in an infinite cause and an infinite principle, it must be infinitely infinite according to its corporeal necessity and its way of being. Bruno asserts:"It is certain that... it will never be possible to find an even half-probable reason, why there should be a limit to this corporeal universe, and, consequently, why the stars, which are contained in its space, should be finite in number". At the same time, we notice that the new gospel of the cosmos is presented throughout the process of knowledge renewal that reformulated the Renaissance era. Across the two worlds - medieval theology and the great systems of the seventeenth century Bruno, aiming to respond to the totality of man's experience, proposed a philosophy of nature. However, being different from Machiavelli's brute force with an infinite potential of "virtue", Bruno's potential is eradicated in the individual in the universe, and the legitimacy of power consists in consensus, rather than force. The driving mechanism is "love-Eros" among or between the intersubjective variations, namely, the reality of an organic universe. Therefore, the aim of politicians is to create, to identify and to guide the desires expelling from the nature of man - love. In addition to the reflection on ontology, this mechanism is endowed with a "praxis" dimension as well. In such an approach, the intrinsic mission/goal of a philosopher or a politician is to be an ancient magician. It is through this methodology that Bruno binds the approach of ancient magic together with the new organic cosmology.

\section{REDEFINITION THE MATERIAL: MATERIAL IS UNIVERSE}

It will be comprehensible if we start from the perspective of the defense for the infinite universe, where Bruno assigns the word a value that clearly goes beyond the cosmological sphere to assume a more complex and deep metaphysical meaning.

From the physical standpoint, "immense and infinite universe" indicates "the compost" of the "innumerable stars, planets, globes, suns and earths" that move in it, and concludes itself in the identity. Ontologically treated as an organic being, the universe is the unique infinite substance, based on which the innumerable accidents can generate.

In the same way, in this profound renewal knowledge, Bruno strives to constitute a philosophy that responds to the totality of man's experience. In this sense, his organismic cosmology leads to a new metaphysical vision and a moral reform. Furthermore, it requires a rethinking of all the essential principles, from the concept of God, to that of material and man. During the sixteenth century, as for the theory of the infinite universe, man could not conceive of the cosmos without a systematic recourse to the experience. Consequently, this concept remains essentially speculative. While modifying its cosmological perspective, science must justify itself in front of the theological tradition. Bruno does not escape this paradigm: since God is the infinite creative power, hence even the universe is the infinite effect of that infinite cause. If God is the internal architect of the infinite realities that constitute the universe, naturally, He manifests also the universe itself as in its totality and

\footnotetext{
${ }^{3}$ Bruno, Giordano, La Cena de le Ceneri, in Opere Italiane, Laterza, Bari, 2006, p. 73.

${ }^{4}$ Ibidem.

${ }^{5}$ Bruno, Giordano/ Ciliberto, Michele (ed.), De l'infinito universo e mondi, Filoteo: dialogo III, in Dialoghi filosofici italiani, Mondadori, Milano, 2000, p. 377.
} 
infinite creativity. From the theological view, God is "Mens super omnia"(mind is above of all), which out of the universe and the reach of man's rational capacities; instead, from the view of reason, by constituting itself as the privileged object of philosophical discourse, God is "Mens insita omnibus" (mind is present in all things), the immanent principle of the universe, therefore, accessible to man's ratio(reason). If in the universe everything is life and death is only the apparent, hence everything changes and "nothing is annihilated", and everything takes its part in the universal and organic life. Therefore, on one side, God is manifested as the universal form, an intellect or soul that fills enlightens and moves everything; on the other side, as the material, God is the unchanging substrate and always present in the things. In short, the material and the form are the identical reality.

The concept of material appears radically changed: endowed with an intrinsic active principle and movement, the infinite creativity is dispersed everywhere. It is moved and animated by the vital forces and likes an immense living organism. Moreover, the material is not something separated from the form, as soul and corporeal are two the aspects of a single universal and infinite being which is called Nature, corresponding to the One-all doctrine of the Eleatic School.

Firstly, in the most famous vulgar Italian dialogues De la causa, principio et Uno (1584), absorbing and reworking on the ancient and medieval wisdoms, Bruno debates for his perspective of the organic universe, but represents it in the new significance.

The five dialogues of the work are specifically concerned of an ontological theme: the distinction between the concepts of cause and principle; that between form and material; the difference between corporal and incorporeal substance toward the motive of the One, in which Bruno integrated the elements of Heraclitus, Parmenides and Nicholas. It doesn't concern a question of the theological One, but rather of the One-universe when contrasted to the concrete beings, which represents the unity and multiplicity at the same time. The essential discovery of this operation depends on the new definition of material, which identifies itself with the infinite Life-material. Namely, it is absolutely the unique simplest and indifferent power, from which all things are derived and their conceptions will be developed and deepened.

Continuously, Bruno's original theory is improved in his Latin work Lampas triginta statuarum (1587) . In Lampas, the strategy of writing is full of the mythological metaphors when he is revealing the doctrines of material, the problem of unity, the notions of substance, virtue and power, the themes of concord and contrariness: the thirty fantastic statues described by Bruno have a dual propose and function. Firstly, they are intended to constitute a practical support for storing the knowledge's data; and then they will illustrate the intimate connection with the ontological structure of the reality. Chaos, Orcus and Night are the three ineffable principles, which designate the various degrees of the natural order. The three metaphors also prefigure material's rich and fecund nature, which is conceived as a prolific "womb" from which will germinate innumerable individuals and worlds.

The Chaos assumes the connotations of the vital material, which can become anything from time to time. It is the Chaos's emblem that vicissitudinally they possess a potential to become everything; they are the fecund infinity and the distinctive traits of the universal material. The Orcus, the second ineffable principle, presents its features as the condition of demand and privation in which the material principle is found. However, for Bruno it is no longer treated as a limitation or a deficiency, on the contrary, it becomes the

\footnotetext{
${ }^{6}$ Bruno, Giordano/ Angrisani, Isa Guerrini (ed.), Candelaio, Rizzoli, Milano, 1976, p. 7.
} 
conditions of vigor and fertility of universal material. In fact, the Orcus is the "father of every vicissitude", , because it makes everything, as it is eager to become everything, potentially be able to settle itself in everything.

The Night, the universal material reveals its own existence beyond the vicissitudinal motion of the entities, through which it expresses itself in infinite forms. Through the complex plurality of perspectives, it becomes possible for Bruno to speculatively visualize the universal life in which the material is the immutable principle of the realities.

In the light of his theory of the infinite and universal material, every being ontologically has the common substance and the same destiny. Bruno overturns the classical ladder of Nature, which describes an immobile and hierarchically structured universe. It is transformed to a tie of vicissitudinal cycle, in which the arrival point traces back to the starting one. This can be defined in relation to an idea of the primordial infinite material:

"I let that the efficient of these things, called by you with a common occurring in the artificial things",

During the medieval period, even though the theory of material or corporeal is almost ignored under the oppression of the rigid Christian theology, we can trace this indistinct but incessant clue among the most famous theologians, from which Bruno set off to chase his nova philosophy.

This doctrine elaborated by San Augustine in his commentary on Genesis (Gen. Litt., PL, 34) ${ }^{9}$, is connected to the Stoic and Neoplatonic concept of rationes seminales, which detects a breeding ground that contains the germs of all forms in the primordial material. The acts that take place on the surface of material are in a potential condition and are perfected by expanding themselves in the successive degrees, but, only thanks to an exterior effort. Also San Thomas (Metaph., VII, 1.8) ${ }^{10}$ has deducted on a similar horizon, which identified in the inchoatio of the form. It exists in the material which considered as the germ of the complete form, and can be actuated only by an efficient and natural effort. In particular, Albertus Magnus (De praed., V, 4) ${ }^{11}$ underlines that the "desire" possesses an indistinct and primitive form that reflects itself in many specific forms. Precisely, desire is assumed as a particular form to witness the intimate perfection of the material. With different contexts, Bruno recuperates and develops these themes: first, in the mnemonics work De umbris idearum (1582); and then in the magical treatise Lampas, where the doctrine of the incohatio is integrated to the Anaxagorean image of the omnia in omnis; finally, in De vinculis in genere (1591), he returns to affirm the innate perfection of the material, which aspires to be transfigured into all the things.

Therefore, the infinite material can be "perfecta imago et simulacrum" ${ }^{12}$ of the divinity. In fact, Bruno observes that this infinite effect is rightly called "universum", because the images and simulacrums converge to compose an organic totality with it.

\footnotetext{
${ }^{7}$ Bruno, Giordano/ Bassi, Simonetta, Scapparone, Elisabetta, and Tirinnanzi, Nicoletta (eds.), Lampas triginta statuarum, in Opere Magiche, Adelphi, Milano, 2000, p. 965.

${ }^{8}$ Bruno, Giordano, De la causa principio et uno, in Dialoghi filosofici italiani, p. 270.

9 Augustine of Hippo, La Genesi, II: La Genesi alla lettera, Città Nuova, Roma, 1989, pp. 245-486.

${ }^{10}$ Thomas of Aquino, Opera Omnia Summa Diligentia, Liber VII: Sententia libri Metaphysicae, apud Dominicum Nicolinum \& socios, Bologna, 2014.

${ }^{11}$ Albertus Magnus, Opera Omnia, De praedicamentis; pp.194-236, Alberti Magni e-corpus online(http://albertusmagnus.uwaterloo.ca/).

${ }^{12}$ Bruno, Giordano, De Immenso et innumerabilibus, seu De Universo et mundis, cited from the italian translation by Giovanni Gentile in Giordano Bruno e il pensiero del Rinascimento, Vallecchi, Firenze, 1991.
} 
Based on this unity which represents the immanent foundation of the natural life, we can comprehend "all the being" owing to that afterward all the determinations manifest themselves "in these sensitive bodies explicitly",

\section{MINIMUM COINCIDES MAXIMUM, INDEFINITUM IS INFINITUM}

Bruno's cosmology and ontology are deeply influenced by the dialectics of Nicholas of Cusa. Nicholas describes the One infinite being as the two complementary aspects, which sustains and innervates each finite accident. In Bruno's Italian work Spaccio de la bestia trionfante (1584), he established that "the principle, the manners and the end; the birth, the increase and the perfection of what we see, is from contraries to contraries, is neither contraries, nor contraries" 14 , the "Cardinal of Cusa" is firstly considered as "that philosopher who is known by the reason on 'coincidence of contraries","15, and then explicitly mentioned:

"that his divine principle of commensuration and coincidence of the maximal and minimal figure; namely, one who recalls the minimal number and another who recalls the maximal number of the angles" 16 .

By referring to chapter fifteen of the first book of De docta ignorantia (1440), Bruno, in a particular manner, lauds the "contemplation of the equality that exists between the maximum and minimum, between the external et internal" $"$. In the initial chapters of the work, Nicholas theorizes that the absolute maximum must be also in relation to the smallness as well as to the greatness; since as the truly maximum, it is necessary that God would be also "of which there is nothing smaller. And since the maximum is revealed by the same way, it is clear that the minimum coincides with the maximum": Nicholas continues "the maximum quantity is maximally great, the minimum quantity is maximally small, . Excluding the big and the small, he disconnects the maximum and the minimum from the quantity with an effort of the mind: then you can clearly see that the maximum and the minimum coincide with each other. In fact, the maximum is superlative, so is the minimum. Therefore, the absolute quantity is neither the maximum nor the minimum, since in it the minimum and the maximum coincide with each other mutually. Extending the reasoning from the scope of quantity to any kind of determination, Nicholas concludes that:

\footnotetext{
"the absolute maximum is absolutely above of any opposition. And since the absolute maximum can absolutely become all the things that can be and without any opposition. Therefore, the minimum coincides with the maximum, it is also above all affirmation and negation",20.
}

The transform from the absolute maximum and contractive unity to the "one being", that is, the coincidence between the maximum and the minimum, conveys a new meaning to the motive of the contraries. The two extreme poles directly connect to the idea of the One-

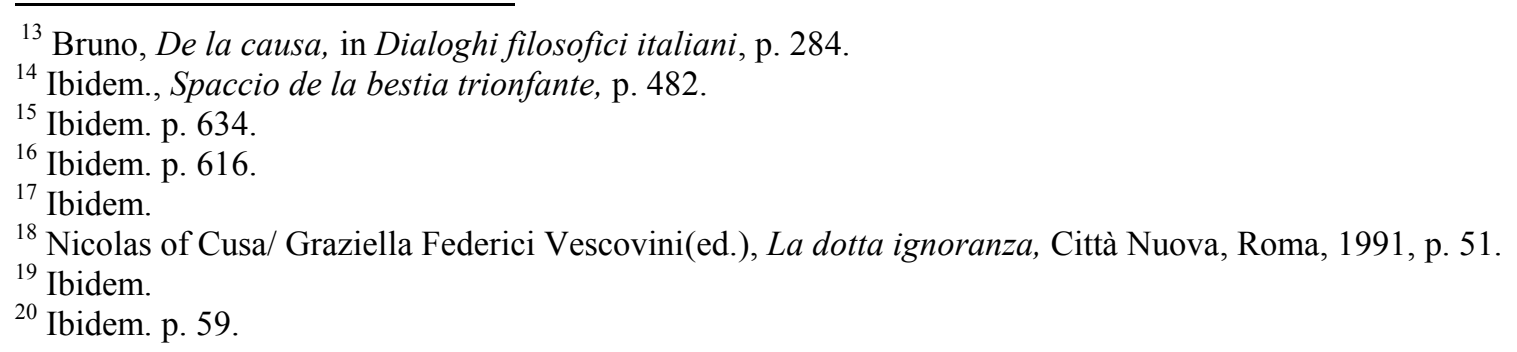


all, which represents the foundation and origin of natural life. Generally speaking, "the contraries are turned into one and indifferent".

\section{THE CONSERVATIVE ASPECT OF NICHOLAS: INDEFINITE DOES NOT EQUAL INFINITE}

However, in fact, Nicholas observes that "absolute maximum" is "the infinity in the negative sense, because it can only be realized in its full potential",21; while the universe embracing "all the things that are not God, cannot be infinite in a negative sense, even if it is without ends and is infinite in a privative sense, 22 .

Consequently, his infinite universe must be understood exclusively in senses of its temporal and spatial dimensions, unlike the brunian complete without setting the preconditions, namely, a perfect and absolute realization. Furthermore, the existence of the universe represents a "decline" when compared with the demand of an intervention from the third maximum, which is contracted and absolute simultaneously. Obviously the third maximum - Christ, introduced by Nicolas, can redeem the universe's dispersion and then bring it back to the extreme divine origin.

On one hand, Nicholas overcomes the vision of a limited universe, which is "very perfect in sense of the order of the nature" and "[precedes] all the things in order that anything can be in anything"; on the other hand, through the distinction between infinitum and indefinitum, he emphasizes the ontological subordination of the universe to the God. The nature of universe is weakened with respect to the third maximum which is identified as Christ, who perfectly realizes the nature of man as a "microcosm" and takes role of the intermediator between the "intellectual nature and the sensitive nature", in other words, the third maximum contains "all the universes" in himself. ${ }^{23}$

Therefore, between God and the universe, Nicolas introduced Christ and treats him as a perfect contract and absolute union which summarizes the true God and true man. Christ is endowed with the whole creation and related directly to the absoluteness of the Father.

Bruno criticizes this profound contradiction in Nicolas' doctrine mainly from two perspectives: firstly, Bruno insists a radical rejection of the mediation between creator and creature which is incarnated by Christ. Bruno uses the metaphor of the centaur Chirone to describe Christ: "man is inserted to beast", "beast is stuck to man", "in which a person consists of two natures and two substances concurrent in a hypostatic union" 24 ; secondly, the necessity of identifying a mediation between God and the universe is disrupted. The transformation of such a role from the "filium dei unigenitum" (the only child of God ) to a "explicatio" (explication, namely the reality of Universe), the relationship of generation and equality that Nicolas has established between God and Son is transposed. The universe does not indicate the dispersion or decline anymore, but rather a full and complete expression of the infinite divine power. As a result, the process of Salvation is no longer needed.

Bruno is convinced that attributing infinity to the universe is the nuclear of the new configuration of the relationship between God and the universe; in this perspective, the former ends up representing the inexhaustibly productive source of the latter. Escaping from the Creator's transcendence and alterity with respect to the creation, an infinite cause and its

\footnotetext{
${ }^{21}$ Ibidem. p. 107.

22 Ibidem.

${ }^{23}$ Ibidem. pp. 165-6.

${ }^{24}$ Bruno, Spaccio, in Dialoghi filosofici italiani, pp. 664-5.
} 
corresponding effect characterize the internal excellence and deprive Nicolas' attempt of redemption. The nature of ultimate foundation is an essential unity, in which everything in the universe exists in the plurality. That is already included in its own perfect identity.

In this sense, Bruno's God is "simple and indivisible", but in such a way, God can "be for everything, be in everything",25; moreover, it is precisely because "simplicity" is redefined by introducing the necessity to differ one its own from another, and according to the "simple divinity" which is "found in all things", the "the nature of fecundity, conservative mother of the universe is projected on different subjects and distributed in different names, individuals in the nature are able to interact with one another ."26

In short, Bruno's conception of God and his simplicity reconfigures the relationship with a universe that is rooted in its own plenitude divine nature. As clarified in the $D e$ gl'heroici furori (1585), the "monad which is the divinity" and "this monad which is the nature, the universe, the world"27, which represents the "geniture", are projected as two aspects of the same "organism", "and destined in the generated and being generated, or being produced and produced",28.

\section{THE SOURCES OF MAGIC FROM FICINO AND AGRIPPA}

Bruno, compared with Galilei Galileo, is not a very good scientist. As a matter of fact, Bruno's universe-view is vitalistic, magical. His planets in the universe are animated beings that move freely in the space of their own as assumed by magicians or of astrologers. In the field of Magic praxis, in order to study the artifices and consensus of love-Eros, Bruno firstly reads the Neoplatonism works of Marsilio Ficino with great attention, particularly the following two of his works: Theologia Platonica (1482) and De vita coelitus comparanda (1489).

Commenting on Plato's Convivium, Ficino underlines the remarkable diffusive force of the Eros daemon, who is capable of tying the three levels of natural things, "superior, inferior, equal" 29 . With this modality, in order to realize the communication between man and God, Ficino eliminates the disproportion between finite and infinite. Superior and inferior realities are linked by a dependent relationship, as the former are "causes" of the latter, and the latter is "effect" of the former; the same things are joined together by sharing of the same nature. The action of love-Eros as a cosmic "vinculum" (link), which is emphasized ontologically in the cosmos by Ficino, is properly inserted into this network. That God reaches the corporeal characterizes the descending phase of the movement and the opposite direction are represented by the process that the corporeal traces back to the Creator. Simultaneously, involving the entities united by a similar level of beings, the love of the superior things towards the inferior one is realized by governing and controlling power of God to the angels, souls and bodies. The inferiors' love for the superiors consists in the desire which drives the souls: once being integrated into the corporeal nature, the necessity of the blessedness of the celestial realities is desired. In consequence, the celestial realities will venerate the divine majesty. "The love on the intra-level coincides with the spontaneous

\footnotetext{
${ }^{25}$ Ibidem., De la causa, p. 80.

${ }^{26}$ Ibidem., Spaccio, p. 634.

${ }^{27}$ Ibidem., De gl'heroici furori, p. 921.

${ }^{28}$ Ibidem.

${ }^{29}$ Ficino, Marsilio/ Pierre Laurens (ed.), Commentaire sur le Banquet de Platon, De l'amour, Belles Lettres, Paris, 2002, p. 53.
} 
tendency - the desire for a mutual unification among the same entities, just as the sensual desire among the same species". ${ }^{30}$

From such a perspective, the meeting point between those who wield power and those who yield it finds a place of compensation and equilibrium - the so-called consensus. From ficinian Neoplatonism magic, Bruno is conscious of that an organic universe or society does not root its decisions so much on force and violence.

Rather, the point is that man's desire is of a connective nature, it seeks union. Thus, the corporeal erotic is a primarily foundation being able to accept both instinctual elements and ethereal and mystical contemplations. In the context of magic, the ontological term material is transferred into corporeal intentionally by Bruno, namely the senses and bodies become the basic studies of the art of consensus. At this critical turning-point, Bruno assumes a separate theoretical direction different from Ficino. Bruno contrasts Ficino's position about the communication between man and God. In Theologia Platonica, where the soul, "third essence or intermediate essence",31, is confirmed by Ficino as a "vinculum of the whole nature". The third essence possesses the "vires" (capacities) of all the beings and therefore is "vinculi fons" (the source of the vinculum), whose eternal, indivisible and indissoluble nature ensures the self-existence of the universe.

Although having some variations in De magia naturali (1590) and De vinculis in genere (1591) , Bruno also makes the reference to the same "ladder" metaphor of the being. However, instead of on the Eros daemons, or third invisible essence, Bruno pays his attention directly on man, as a subject privileged of the magic praxis: "the men" - as written at the beginning of De vinculis in genere- "connect or subordinate to the vinculums or are themselves vinculums or conditions of the vinculums",32

As a matter of fact, the classical ladder among the beings is not a connection, but separation. The loving connection identified by Bruno, on the basis of a unique principle, connects the homogeneous components. The world, then, is configured as One order, as a complex but well-organized structure. By this way, in De magia naturali, Bruno acquires a profound meaning and returns to the theme of the link of love-Eros, which then becomes the principal argument of De vinculis in genere. Both of the two magical works further highlight the two main elements which has been already presented in the mnemonic work Sigillus sigillorum (1583): the love-Eros, by which we can reign the magic; the magic, which allows the complete and global vision of the natural world, and at the same time sheds light on the new discovery of the corporeal infinity.

Another author who is always present in Bruno's magical works is Cornelius Agrippa, who leaves a summa of the Renaissance magic - De occulta philosophia (1533) which was widely diffused during the sixteenth century.

Though the chapters' structure of De occulta philosophia is constantly imitated by Bruno, this does not indicate that the doctrine is faithfully reproduced. By some significant modifications, Bruno detaches himself radically from Agrippa's original ideas: first of all, on the crucial theme of the life and the universal animation, Agrippa states that it would be absurd for the beings such as worms and flies to be alive and animated indifferently as like the noblest body in the universe. When following the pace of De occulta philosophia, Bruno raises a question of a different order: comparing to the single corpuscles, the universe

\footnotetext{
${ }^{30}$ Ibidem.

${ }^{31}$ Ibidem. p. 13.

${ }^{32}$ Bruno, Opere Magiche, p. 47.
} 
doesn't contain much superiority. Moreover, it is the individual components that determine the animation and vitality of the cosmos, the soil and the water, because this womb will "generate, enliven and raise plants and animals" 33 . Secondly, with regard to a training of the solitude as indispensable for obtaining intellectual purity, Bruno makes reference to the chapter fifty-three of the third book of De occulta philosophia in which it is shown how to prepare to receive an oracle; but this direction is not consistent with Agrippa's theoretical foundation in which the transcendental vaticination and the divine selection are integrated. As already asserted in the Sigillus sigillorum, for Bruno the solitude and interior recollection are constitutive; anyway, each form of magical operation does not derive from a possession of the agent from a superior being.

\section{THE ESTABLISHMENT OF NATURAL MAGIC}

Differently from the Renaissance pioneers of magicians, Bruno sets an explicit aim for the domain of application of his natural magic, namely, from the natural universe to the civil humanity.

We should remember that already in Spaccio de la bestia trionfante, by placing a eulogy of the Egyptian magic and the ancient magicians, Bruno has criticized this poison of Christian religion. Within this scenario, based on the operative element, the appeal for the magic offers Bruno an effective approach to the divine: "[corpuscles] climb to the top of the divinity with the magical and divine rites for the same ladder of nature, therefore, the divinity descends to the minimal things for the communication with its own ",34.

The emancipation of natural dimension is also based on the explosion of the material, always being the crucial foundation of the whole system of Bruno: through the metaphor of mirror, he explains how each fragment of natural reality represents the divinity, wherever it is located:

\footnotetext{
"The spirit then [...] as to its particular and individual being, intend and intends that it produces again as the number of the forms and types - fragments of the mirror as many as the entire mirrors - result from a huge general mirror, which is a life, and represents an image and a form by division and multiplication of sub-level parts" ${ }^{, 35}$.
}

As illustrated above, it is precisely in this step that the connection between the Latin works published by Bruno in 1582-83 and the Italian dialogues is separated from each other: that theory in Sigillus sigillorum is considered as a manifestation, and achievable measure then becomes the object of the research and reconstruction, that is, the unity of the life of all the things, one single light in all the things, one sole goodness, the unity of the sense; loveEros, as a bridge, enables the textures of the infinite reality to be reorganized, but always in a non-definitive way, the infinite Life-material is in all, it is all, all can be done and the magician uses the arts to know and to operate the natural world, that is further understood as a great and powerful method of mediation.

Thus, abandoning the traditional treatment for divine being, Bruno concentrates on those vinculums that enable the natural magic to operate directly on civil creatures. This secular praxis is achieved by the influence and the guide to the individuals' interior activities. According to Bruno, the necessary components of each magical intervention

\footnotetext{
${ }^{33}$ Ibidem., De magia mathematica, p. 23.

${ }^{34}$ Bruno, Spaccio, in Dialoghi filosofici italiani, p. 632.

${ }^{35}$ Firpo, Luigi/ Quaglioni, Diego (ed.), Il Processo di Giordano Bruno, Salerno Editrice S.r.l., Roma, 1993, p. 301.
} 
consist in three crucial factors: "active power in the agent; passive power or disposition in the basis in which the action occurs [...]; finally, appropriate application ${ }^{, 36}$. To effectively interact with these three components, we must operate at the level of the reality which is characterized by a constitutive way of its own movement and difference. Since the magician's praxis does not require a series of rigid precepts, rules or rites, once established, it could simply be put in effect; but the demands for a deeper knowledge of the Nature, in specific terms, according to the effective definition by the De vinculis in genere, that is, its rhythms and its principles, a "universal theory of things", are still needed. Accompanied by an ultimate ability to distinguish and to evaluate the natural principles over and over again, the praxis has to include the most appropriate strategies for the establishment of the relationship between "agent" and "material". In the universe, single being does not carry per se an absolute and stable character; however, the magician, through acknowledging the always changing relation between "agent" and "material", is able to acquire a relative value of such relationship.

Therefore, the magic operator must be conscious of that "neither anything is proper passive, nor active with respect to any other,"37. Trying to achieve a peculiar form of correspondence, according to the principle of Aristotelian inspiration - "action of the actives on the well-disposed passive, 38 , finally the magical attempt can achieve a peculiar form of correspondence. As a result, a secular magician must acquire an adequate knowledge of Nature, and be enriched by the endowments of "far-sightedness" and "precocious reflection". Through establishing "in advance the moment for conducting the link" and seizing "the favorable occasion with the maximum speed" 39 , the magician can control the appropriate links.

\section{BRUNO'S POLITICAL PRAXIS: THE PATTERN OF A NEW SOCIETY}

Bruno's magical praxis is far from the traditional physiognomy of the "ritual" and enchantment. Rather, it is based on the study of those psychical and passionate conditioning forms, which is capable of generating an integrated participation of the individual. It will be up to Sigmund Freud after several centuries in his famous work on mass psychology and analysis of the ego in 1921 in which he studied the same psychological phenomenon and the relation between the individual and the power seen from both of individuals and the masses.

Through an ontological scenario defined by the continuous metamorphosis of the material in his works on magics, Bruno pursues the man's potential interacted with the natural rhythms and he is completely immersed in the significant political implications via a magical art. Developing the connection between magical praxis and artifices of convincing the human minds, the magician who intends to become a cautious politician has transfigured into an "animorum venator" (mind's hunter) in De vinculis in genere. The role of a magician is described in the act of seducing the citizens through an instrument of persuasion, which leads the passions and inclinations in order to finally drive them towards the direction of One organic life.

Practically, the art of rhetoric maintains a privileged relationship not only with political praxis, but also with the magic one, alike Aristotle's partial opinion. Usually, orator and vinciens(connector) both share the consideration of what is proper to themselves and

\footnotetext{
${ }^{36}$ Bruno, De magia naturali in Opere Magiche, pp. 251-3.

${ }^{37}$ Ibidem. p. 253.

${ }^{38}$ Ibidem.

${ }^{39}$ Ibidem., De vinculis, p. 447.
} 
what "be pleasant to those who must be enchanted and tied, evaluating their customs, their status, their characters (la sua complessione), their habits" 40 . In the "civil conversation", there is no effective link without affective involvement of both subjects in the relationship, that is, "if (s)he who is linked is not in turn subjected to the tie, it is not possible to link with oneself"; analogically (s)he has to talk about the orator that "the passion cannot be aroused without passion."

Therefore, obviously the passion and desire for the Bruno's organic universe can be generated from love-Eros for the mundane life of its infinite expansion. And in his organic universe, Bruno considers and desires all beings to be alive, all to be animated. And from this doctrine, his predilection for the magic is derived, which is based precisely on the presupposition of a universal panpsychism aiming to take possession of the natural world with artifices, just like a lover casts a magic net with gestures, words, services and gifts around the object-subject of his love. Similarly, a "society's magician" casts the net of his fantastic vision over the world in order to capture his "prey" by means of his consent.

From this perspective, the art of politics acquires a profoundly new meaning. By entering directly into the interior dynamics, the politicians are able to influence the behaviors of the masses. Therefore, neither force nor destructive violence could drive man's passions. On the contrary, the relationships between men are organized by a new form of obligation which introduces force and power from the knowledge and application of the principles that are subjected to the continuous flow of the nature. A hierarchal division is transfigured into a consensual relationship among the components of the magical-political praxis.

The brunian citizen is a lover to be raped and tied. Bruno defines this chain of operations "vincolare" (to win). His "condispositio" and new "ratio" (reason) give the generic name to ties, that is "vincula". 42

\section{CONCLUSION}

I regret to claim, Bruno has a modern rational mind by no means. However, his conception of the organismal universe and society is so powerful and so prophetic, so reasonable and so poetic that we cannot but admire it and him. And his thoughts deeply influenced modern politics and philosophy. In fact, nowadays many historians and intellectuals consider that his works on magic are intelligent and offer political insights for understanding the behavior patterns in the contemporary social life. Thus, we must admit Bruno's importance in the history of the human mind.

\section{BIBLIOGRAPHY:}

[1] Koyré, Alexandre, From the Closed World to the Infinite Universe, Johns Hopkins University Press, Baltimore, 1957.

[2] Bruno, Giordano, Opere Italiane, Laterza, Roma and Bari, 2006.

[3] Bruno, Giordano/ Ciliberto, Michele (ed.), Dialoghi Filosofici Italiani, Mondadori, Milano, 2000.

[4] Bruno, Giordano/ Angrisani, Isa Guerrini (ed.), Candelaio, Rizzoli, Milano, 1976

[5] Bruno, Giordano/ Bassi, Simonetta, Scapparone, Elisabetta, and Tirinnanzi, Nicoletta (eds.), Opere Magiche, Adelphi, Milano, 2000.

\footnotetext{
${ }^{40}$ Ibidem., De magia naturali, p. 269.

${ }^{41}$ Ibidem., De vinculis, p. 487.

${ }^{42}$ Ibidem., De vinculis, p. 497.
} 
[6] Bruno, Giordano/ Matteoli, Marco, Sturlese, Rita, and Tirinnanzi, Nicoletta (eds.), Opere Mnemotecniche, Adelphi, Milano, 2004, 2009.

[7] Ciliberto, Michele, Giordano Bruno Parole, Concetti, Immagini, Edizioni Della Normale Istituto Nazionale Di Studi Sul Rinascimento, Pisa and Florence, 2014.

[8] Bassi, Simonetta, L'arte Di Giordano Bruno Memoria, Furore, Magia, L.S. Olschki, Florence, 2004.

[9] Rossi, Paolo, La Nascita Della Scienza Moderna in Europa. 6.th ed. Laterza, Roma and Bari, 2009.

[10] Augustine of Hippo, La Genesi, II: La Genesi alla lettera, Città Nuova, Roma, 1989, pp. 245 486.

[11] Thomas of Aquino, Opera Omnia Summa Diligentia, Liber VII: Sententia libri Metaphysicae, apud Dominicum Nicolinum \& socios, Bologna, 2014.

[12] Albertus Magnus, Opera Omnia, De praedicamentis; pp.194-236, Alberti Magni e-corpus online, http://albertusmagnus.uwaterloo.ca/, 09.05.2018.

[13] Gentile, Giovanni, Giordano Bruno e il pensiero del Rinascimento, Vallecchi, Firenze, 1991.

[14] Nicolas of Cusa/ Graziella Federici Vescovini(ed.), La dotta ignoranza, Città Nuova, Roma, 1991.

[15] Garin, Eugenio, Niccolò Cusano e i platonici italiani del Quattrocento, in Niccolò da Cusa. Relazioni tenute al convegno interuniversitario di Bressanone nel 1960, Sansoni, Firenze 1962, pp. 75-100.

[16] Ficino, Marsilio/ Pierre Laurens (ed.), Commentaire sur le Banquet de Platon, De l'amour, Les Belles Lettres, Paris, 2002.

[17] Gentile, Sebastiano, El libro dell'Amore di Marsilio Ficino, in Letteratura italiana. Le opere, I, Dalle Origini al Cinquecento, Einaudi, Torino, 1992.

[18] Ficino, Marsilio/ Errico Vitale(ed.), Teologia Platonica, Bompiani, Milano, 2017.

[19] Vasoli, Cesare, Quasi Sit Deus Studi Su Marsilio Ficino, Conte Editore, Lecce, 1999.

[20] Ficino, Marsilio/ Santinello, Giovanni, Tarabochia Canavero, Alessandra (eds.), Sulla Vita, Rusconi, Milano, 1995.

[21] Firpo, Luigi/ Quaglioni, Diego (ed.), Il Processo di Giordano Bruno, Salerno Editrice S.r.l., Roma, 1993.

[22] Heinrich Cornelius Agrippa Von Nettesheim/ Perrone Compagni, Vittoria(ed.) De Occulta Philosophia Libri Tres, Brill, Leiden and New York, 1992.

[23] Vasoli, Cesare, Ficino, Savonarola, Machiavelli Studi Di Storia Della Cultura, N. Aragno, Torino, 2006. 